\title{
N.I. Ursova
}

Vladimirsky Moscow Regional Clinical Research Institute, Russian Federation

\section{Therapeutic potential of modern probiotics}

\section{Author affiliation:}

Ursova Nataliya Igorevna, $\mathrm{PhD}$, professor, chief research scientist at the pediatric department of the Vladimirsky Moscow Regional Clinical Research Institute (MRCRI)

Address: building 5, 61/2, Shchepkina Str., Moscow, 129110, tel.: +7 (495) 681-25-98, e-mail: ursovan@mail.ru

\section{Article received: 05.11.2012 accepted for publication: 24.03.2013}

This discussion article adduces a short review of clinical studies where the use of probiotics has shown the best results. The issues of whether probiotics are capable of having a protective effect on the intestinal barrier, an antagonist effect - on opportunistic microbes and a stimulatory effect - on the immune system, are discussed. The best studied production species and strains forming probiotic drugs are observed. The differences between monostrain and multispecies probiotics are given. The reasonability of using combined drugs with combinational additive or synergetic strain-specific effects is explained.

Keywords: probiotics, intestinal microbiocenosis, bifidus bacteria, lactobacilli, monostrain, multistrain, multispecies drugs.

As reported, key mechanisms involved in microflora disorders tend to be selective targets for different biological methods of exposure.

The use of the microgerm known as probiotic is considered to be one of the practical approaches to regulatory system recovery [1-9].

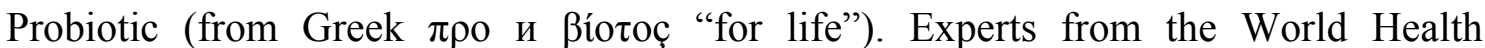
Organization give the following definition: a probiotic is a live microorganism. Probiotics are live microorganisms which, when used in the necessary amount, have beneficial effect on the health of the host organism [10]. According to the data of completed research, probiotic effect can be provided not only by viable or diminished cell (for instance radiated) but also by structural components of the non-viable bacteria (short DNA sequences, peptidoglycane, lipoteichoic acid) [11-16]. It is obvious that there is reason to expand the modern definition of "probiotic".

Mechnikov I.I., the founder or probiotic concept, has been awarded Nobel Prize in Medicine in 1908 for his series of works [17]. Since then there has been made a sufficient number of studies of micro-organisms ( $t$ b. 1), that could be used in everyday medical practice for 
pharmaceutical products and functional foods [15, 18]; however, only a few are officially recognized as such. The main criteria for this are the phenotypic, genetic characteristics and availability of probiotic effect, established in double-blind placebo-controlled studies. More accurate evidence has been obtained for Bifidobacterium lactis, Bifidobacterium longum, Bifidobacterium infantis, Lactobacillus acidophilus, Lactobacillus GG, Lactobacillus reuteri, Lactobacillus casei, Strepto (Entero-) coccus faecium SF68, Streptococcus thermophilus, Saccharomyces boulardii.

It is rational to highlight that the World Health Organization, the US Federation for quality control of food and drugs (FDA), the UN Food and Agriculture Organization (FAO) and other large public and expert groups conclude that probiotics are generally considered absolutely safe and, having a GRAS status (generally recognized as safe), can be put to use without limitations in food and pharmaceutical industry [10, 19].

The abovementioned microorganisms are a part of the pharmaceutical market of medical drugs with different product description: tablets, liquid suspensions, capsules, rectal and vaginal suppositories, ointments and creams.

There is an expanded production of biological forms of drugs in the complexation with interferon, immunoglobulins and vitamins. One of the promising areas today is creation of new generation of probiotics - multivalent or combined with immobilized bacteria of a different taxonomic unit on the assumption that probiotic strains must be biocompatible and have synergistic effect [20].

Our interest and knowledge in sphere of clinical use of probiotics is constantly growing. The accumulated convincing information shows that probiotics penetrating intestinal canal change its microfloral structure and function [5-9, 21-36]. According to what we know, there are three lines of clinical and model determinations contributing to the study of the biological effects of probiotics. It should be noted that strengthening of the scientific base and the need for well-designed and conducted studies of specific factors that are critical in the probiotic therapy are both of major importance.

Tb. 2 shows systemized directions and key questions about the role of probiotic organisms in the development of antibacterial effect, reinforcement of barrier function of epithelial tissue and modulation of immune response [15].

Probiotic intensification of barrier function of epithelial tissue. There is evidence that S. thermophilus and L. acidophilus inhibited the adhesion and invasion of human enteroinvasive Escherichia coli. In epithelial cells, which contacted with those probiotic bacteria, scientists observe an increase in actinine and occludin phosphorylation in dense cell connections. [37]. 
In Caco-2 cell culture there was a strengthening or weakening of dense cell contacts in response to the cell-free supernatants varying in content of released elements. It is found that $E$. coli O157:H7 significantly increased the permeability of Caco-2 cells and released elements, while B. Lactis significantly reduced it [38]. Lactobacillus rhamnosus GG prevented cytokineinduced apoptosis in intestinal epithelial cell model by inhibiting activation of proapoptotic p38/ mutagen activating protein kinase [19].

As has been mentioned, the intestinal epithelium is covered by a transparent viscoelastic gel adhered to the mucosa. Ultrastructure of mucus is presented by muco-glycoprotein polymeric compounds. Mucus is considered to be one of the main factors controlling the intestinal microbiocenosis. Recent studies demonstrate that L. rhamnosus (GG) and Lactobacillus plantarum boost in vitro mucin gene expression (MUC2, MUC3) in colonocytes HT-29, which are able to inhibit the adhesion of pathogenic bacteria [39].

It was shown that the adhesion process of lactobacilli and bifidus bacteria to the intestinal epithelium is implemented by homofimbrial structures and certain components of the cytoderm (lipoteichoic acid, proteins and outer membrane phospholipids) [34, 36]. Nowadays there is objective evidence that L. rhamnosus (GG) has a specific feature of interacting with enterocytes: it concerns the mucin-binding pilidium - distinctive pilomotor structures (pili structure), with the help of which $L G G$ can be firmly attached to the intestinal mucosa [40].

Moreover, during the study of strain-specific capacity of probiotics by comparing Nucleotide genomes it was found that only one of the LGG genomic "islands" encodes the synthesis of the three LPXTG-like adhesive mucin-binding pili and pili-associated sortase [18].

These materials show good LGG strain adhesive properties to the enterocytes, which provide extremely high capacity for probiotic transient colonization and therefore adequate stimulation of the immune function of the gastrointestinal tract.

Antibacterial probiotic effect. The antiseptic properties of probiotics are associated with the production of anti-microbial factors: organic acids and bacteriocins inhibitory proteins. It is important to mention that organic acids appear to be the "weak acids"; more than $90 \%$ of their molecules in the bowel lumen are in the anion dissociated form. These natural metabolites are important for regulating metabolism and absorption in the colon. Under certain physiological and pathological conditions they initially rapidly penetrate through the membrane tentativepathogenic (pathogenic) bacteria that colonize the intestinal mucosa, alter intracellular $\mathrm{pH}$, reduce the potential energy, and accumulate toxic anions lead to ultrastructural defects of bacterial cells, which ultimately suppresses its vital functions [41, 42]. There is evidence that the inhibitory effect of organic acids directly depends on the $\mathrm{pH}$ index; still, there is evidence that at low values stronger antimicrobial activity is observed in lactic and propionic acid, at $\mathrm{pH}>4.5$ - 
in acetic acid [32, 35]. Potential activity in respect to the major tentative-pathogenic microorganisms of such substances as hydrogen peroxide, diacetyl and bacteriocins is a wellknown fact. It was emphasized that high bacteriocins inhibit the closely related species of bacteria that live in the same biotope, and microcins (low molecular weight metabolites) have a wide range of antimicrobial activity, and therefore have more significant bacteriostatic action $[35,41-46]$.

The involvement of nitric oxide (NO) in the development of physiological and pathological conditions is also a dynamic theme of investigations. Many testings show that NO is related to a key signal molecules of gastrointestinal tract; it is synthesized not by the cells of the human body, but also by some commensal germs (E. coli, Lactobacillus) [47, 48]. NO cytotoxic effect is enhanced by association with the acidic environment (bifidus bacteria lower $\mathrm{pH}$ down to 5.0, lactobacillus - down to 4.0). Only in this case nitrites can be generated - these are highly toxic endogenous metabolites disrupting the normal functioning of many tentative-pathogenic and pathogenic microorganisms, besides the ability of normal microflora to be resistant to these compounds has been proved [49]. The peculiarity of nitrites lies also in their ability to potentiate the simultaneous antibacterial effect of hydrogen peroxide and lactic acid bacteria which are formed by saccharolytic bacteria [48].

Probiotic mechanisms of immunomodulation. Special place is occupied by studies examining the capability of probiotics to affect immunological recovery of body using such physiological processes as improvement of the functional capacity of engulfing cells and cytotoxic activity of macrophages, stimulation of the gut-associated lymphoid tissue and the effect on the immunocompetent $\mathrm{T}$ and $\mathrm{B}$ cells $[25-31,34]$.

To date, three main paths of physiologic immune response are discussed. The first one is manifested in the fact that adhesion of probiotic bacteria to the epithelial cells of the intestinal biotype causes the release of cytokines, trapped dendritic cells. Thus, intestinal canal epithelial cells play crucial role in processing the signals that act on the common signaling pathways. Passage of probiotics in the gut lumen can be enough for implementing intercellular communication [50]. The second way is also connected with the mechanisms of cellular effects and consists in the following: $\mathrm{M}$ cells in the follicle-associated epithelium of the Peyer's patches at the surface provide delivery of probiotic bacteria in subepithelial area for subsequent contact with immune cells (macrophages and dendritic cells). There they are recognized by receptors (TLR, CLR, NLR); this leads to the release of cytokines and the expression of co-stimulatory molecules for T cells [11]. The third way is the connection of microorganisms pushed into the lumen appendages of dendritic cells located in the mucous coat [11]. 
The dialectics of complex relationship between the state of intestinal microflora and production of secretory immunoglobulin is of particular interest. Joint data show that stimulation of immunoglobulin (Ig) is accompanied by the increased expression of adhesion receptors and bactericidal activity, thereby forming specific protection. It is assumed that secretory immunoglobulins play an important role in the local immune response. For instance, IgA1 hapten-specific antibodies with heavy chains having affinity with mucositis ensure the formation of an immunoglobulin monolayer on the surface of mucous coat. Other Ig (subclass A2), having no relationship with the mucous membrane, migrate into the lumen and provide the first line of immune defense against infection. It should be taken into consideration that process-specific adhesion of tentative-pathogenic and pathogenic microorganisms to the mucosa may be inhibited by the presence of other factors, like presence of IgA and lysozyme, which in turn contribute to receptors' adhesion of bifidus bacteria and lactobacilli [39]. More detailed research of IgA role in prevention of the mucosal coat colonization by extraneous bacteria assumed that more than $99 \%$ of bifidus bacteria and lactobacilli are not covered by secretory immunoglobulin. On the contrary, the surface of Enterobacteriaceae, staphylococci, and other opportunistic and saprophytic microorganisms is completely lined with IgA. The available information suggests that immunological tolerance of normal flora is in the basis of this phenomenon.

Important advantage of microflora in the development of immune response should be considered at some point as its universal immunomodulatory effects, including both immune stimulation and immunosuppression [51, 52].

According to the recent experimental studies, probiotics can be attributed to antiendotoxin means. It has been convincingly showed that bifidus bacteria have endotoxin binding capacity; they also reduce endotoxin dependent induction and interleukin (IL) 8 release [39]. There exists another point of view that bacterial lipopolysaccharide and peptidoglycan that are part of different normal flora strains have immunoregulatory effects. In line, it was found that the key meaning of antiendoxive immunity consists not in absolute body protection against endotoxin, but in limitation of its concentration and biological activity to the level required for the physiological functioning of the immune system [53].

The best-studied industrial species and strains in the composition of probiotics. It is obvious that prescription of prebiotic medications should be viewed as pathogenetically justified under different conditions and illnesses, so the range of their application is clearly defined: acute stage of the disease, periods of recovery and prevention therapy. The purpose of such a therapeutic intervention is the proved ability of probiotics to exert a protective effect on the intestinal barrier, antagonistic action - on tentative-pathogenic microorganisms and stimulatory action - on the immune system [54-56]. 
It should be reminded that the term "evidence-based medicine" was introduced in 1990 by a group of Canadian scientists from McMaster University (Toronto) and it suggests such approach to medical practice in which decisions on the use of medical preventive and diagnostic measures are taken on the basis of available evidence of their effectiveness and safety.

In this context, we emphasize that systematic review, meta-analysis and randomized comparative clinical trials are of the best evidence, in contrast to other research options (nonrandomized comparative studies, prospective comparative surveillance studies, retrospective comparative surveillance studies, non-comparative study and expert knowledge). The in vitro studies conducted on animal models are certainly important for determining clinical strategy, but they are not sufficient for approving probiotics' utility for human health. Tb. 3 summarizes clinical studies data in which the use of probiotics rendered better results [57-74].

Recommendation list of basic probiotics includes drugs containing the representatives of only one bacteria kind (monostrain), association strains of one (multistrain) or several types of microorganisms (multi-species), self-eliminating antagonists, combined probiotics and synbiotics. According to numerous scientific testimonies, positive effect on human health can be attributed only to an exact strain (strains), but not species or a group of probiotics $[3,75]$.

In recent years, the science literature provides general opinion about a probiotics' viable usage in clinical practice, however, according to the recent meta-analyses, medications based on lactobacilli and bifidus bacteria do not always have a positive effect on the bacillary environment and biotransformation in the large intestine. Exogenous probiotic survivability changes under the influence of hydrochloric acid of gastric juice, bile acids and digestive enzymes.

The study of these problems showed that different strains of microorganisms' survival rate is estimated at $20-40 \%$ [3]. For better understanding of these events one should consider the recent information about the presence of probiotic resistance to an acid-base healthy environment. In vitro tests showed the 3-5 ordinal reduction in the number of viable bifidus bacteria and lactobacilli firstly in the acid, then - in an acid-based healthy environment simulating human digestion [76]. Subsequently, these data were confirmed by in vitro experiments, in which the model environment was used instead of gastric juice and human duodenal contents. Completed studies have shown that the number of probiotic microorganisms is reduced to hundreds of microbial cells [77]. The results of previous research have been confirmed by direct experiments on animals using labeled probiotics [78]. The final conclusion can be presented as follows: it is necessary to use additional forms of probiotic protection, such as acid-resistant capsules or sorbents to keep probiotic potential, which may be leveled by a number of factors (antibiotics, acidic, acid-base environment, digestive secretions of the gastrointestinal tract, etc.) [77, 79]. 
Fundamentally important from a practical point of view is the question of the optimal single and course doses of probiotic intake. With the expansion of the range of drugs used, we accumulated a lot of evidence that probiotics in high doses and during long therapy courses may lead to side effects [80-84]. For the first time there is evidence that with intrajejunal administration of high doses of probiotic microorganisms test animals have malconditions that in some cases lead to death [80]. There have been several publications indicating that exceeding the daily dose of certified probiotic preparations 5, 10, 100 times is accompanied by progressive increase of dead lymphocytes [81]. Medical practice confirms the ability of different probiotics when used in excessive doses to induce cytokine imbalance, which is manifested by fever, arthritis, hepatitis, increased actual or manifestation of latent autoimmune disorders [85-87]. These proofs make us think of optimizing the duration of probiotic therapy and the possibility of its individualization.

The next important step in the study of positive effects of probiotics is studies comparing features of monostrain, multistrain and multi-species drugs. There is a debatable question of the optimal probiotic culture, which, according to experts, should be mixed. Mixed probiotic strains complement each other's actions on the human body, that is, exhibit synergistic properties. Many studies have served as basis for such a statement, showing that intestinal microbiocenosis is a complex association of bacteria, so topical application with the adhesion will be more successful in multi-species probiotic strain [88-90]. However, one should bear in mind the well-known feature of modern diseases, which is their multi-factor ability to develop. It becomes evident on this premise that rationally combined probiotics with a wide range of physiological effects should be offered as drugs of choice [8, 87]. Such probiotics provide a fundamentally new opportunity to prevent or reduce the risk of multifactor diseases, as probiotic properties are strain-specified [86].

As a practical illustration, we can cite a study made by G. Zoppi et al. [91], who examined the efficacy and effects of 6 commercial probiotic drugs on intestinal microbiocenosis. More than 50 children treated with the help of ceftriaxone therapy were put under the supervision. Probiotic lyophilized drugs in capsules or sachets were prescribed as additional. Three monostrain probiotics were used: S. boulardii, E. faecium SF68 and L. rhamnosus GG. Among multistrain probiotics studies were conducted of a multistrain drug, containing three different strains of lactobacilli: L. rhamnosus $\mathrm{GG}+$ L. acidophilus + Lactobacillus bifidus; multistrain drug, containing two strains of lactic acid bacteria: Bifidobacterium bifidus + L. acidophilus and multi-species probiotic under the title VSL\#3, comprised of a high concentration of bacteria belonging to 9 different strains: S. thermophilus, E. faecium, Bifidobacterium breve, B. infantis, B. longum, L. acidophilus, L. plantarum, L. casei, Lactobacillus delbrueckii, ssp of 
bulgaricus. In accordance with the received data, S. boulardii prescription does not lead to the restoration of the intestinal microbiocenosis. E. faecium SF68 treatment did not eliminate, but exacerbated the existence of dysbiosis aggravated by increase in the number of anaerobic cocci. Only L. rhamnosus GG showed high activity towards the major tentative-pathogenic microorganisms. As it turned out, in groups where S. boulardii and L. rhamnosus GG were applied there was an increase in the potential risk of bacterial resistance to $\beta$-lactam antibiotics: in particular, the number of samples with positive results to presence of $\beta$-lactamase rose to $83 \%$. All the studied probiotics led to a decrease in fecal $\mathrm{pH}$ and only for multi-species this result was statistically significant. The latter fact should be regarded as positive, as the acidic environment inhibits the growth of pathogenic microorganisms and reduces the activity of proteolytic bacteria. The proof of success of probiotics of multi-species treatment of antibiotic-associated dysbiosis is the data, showing a significant reduction in the risk of gastrointestinal symptoms, normalization of aerobic/anaerobic microbial populations' balance and the absence of antibiotic resistance of fecal microflora. Hence, multistrain probiotics are more promising than traditional monostrain ones, because they show high effectiveness in preventing antibiotic-associated dysbiosis among children. Other clinical studies have shown that prescription of multi-species probiotic VSL\#3 for patients with ulcerative colitis and ileitis reduces the need in antibacterial agents and prevents the development of bacterial complications that monostrain probiotics are not capable of $[12,13,89,92,93]$.

Another example of an experimental study of anti-infective focus of probiotics. By design, laboratory mice were randomly assigned to receive skimmed milk diluted with drinking water (control set), based on L. acidophilus, or L casei, or combinations of both strains for 8 days. Then all the animals were infected with Salmonella typhimurium, and then at various time intervals the number of viable pathogenic bacteria in the liver and spleen was microbiologically determined, serum antibody concentrations to S. typhimurium were analyzed; mice were observed for 21 days. It appeared that milk fermented with probiotic monostrain did not increase pathogen test resistance, although the initial survivability of animals was higher than in the set group. Fermented milk product enriched with strain L. casei caused a significant decrease in the number of Salmonella in liver and spleen on the $10^{\text {th }}$ day after infection and led to the better marked specific antibody production than in the set group.

At the same time, the lowest antibody titer was observed in animals treated with the $L$. acidophilus. The results are interesting, because the combination of L. acidophilus and L. casei, activating immune defense factors, contributes to the effective elimination of pathogen and creates conditions preventing the spread of acute intestinal infection in mice and premature death of laboratory animals. Thus, the period of liver and spleen debridement was 7 days, in the same 
time period high values of serum antibodies to S. typhimurium were established, and by the end of the experiment the survival and recovery levels of all laboratory animals were stated [94].

Similar results were obtained in other experimental studies, according to which the most promising probiotic to demonstrate its antagonistic activity against enterotoxigenic E. coli (E. coli O157:H7) and salmonella (Salmonella enteritidis, S. typhimurium) appears to be multispecies probiotic drugs [95-97].

Based on the detailed review of clinical and experimental studies with analysis of multispecies probiotic drug properties (tb. 4), it was found that the latter will have the highest possible survival rates, as these rates for the ingested probiotics is different for separate genera, species and strains of bacteria [87-88]. Probiotic strains may cause local reduction in acidity of intestinal contents, creating a favorable environment for the formation of the colonization capacity, particularly of acidophilus bacteria. Certain probiotic strains have the properties of the substrates disposed to form organic acids that have a beneficial effect on the intestinal mucosa coat. For example, Lactobacilli produce lactate, which is metabolized by propionibacterium into propionic acid [98].

In vitro tests prove that some probiotic strains (S. Thermophilus) create anaerobic conditions which allow strict anaerobic bacteria such as bifidus bacteria reproducing on the mucosal surface and remaining viable during passage through the gastrointestinal tract [99].

Furthermore, it is known that a wide range of physiological effects of probiotics is related to their ability to adhere to mucus and epithelium of the mucous membrane of the intestines. Interesting and quite unexpected results were obtained during the in vitro properties' study. It was found that L. rhamnosus GG or L. delbrueckii subspecies bulgaricus increased adhesion of Bifidobacterium animalis BB12 more than twice. A similar situation was determined for Propionibacterium freudenreichii P6, which increases the adhesion more than 3 times in the presence of L. rhamnosus GG and almost twice - in the presence of B. animalis BB12 [100, 101]. These examples demonstrate that the stimulation of adhesion of one strain to another optimizes multi-species probiotics colonization process. Moreover, until now, propionibacterium representing part of the normal human microflora has never been used as a probiotic due to the low adhesiveness. The above data will critically review the quality, functional activity, synergistic effects of microorganisms belonging to the fixed multi-species probiotic combination. This can also be applied to the promising types of probiotic bacteria, including propionibacterium.

Results of a clinical study of gluten-hydrolyzing strains of probiotics (L. acidophilus 311, L. acidophilus 180, L. casei 925a, L. casei 4628, B. longum 17 xs and Propionibacterium avidum 1) in 25 patients with celiac disease have become convincing evidence. High efficiency 
of such strains could be observed in comparison with therapy using commercial probiotic equivalent dose. It has been shown that multi-species strain is accompanied by a significant probiotic therapy is accompanied by significant duration decrease of clinical symptoms of the disease, gastrointestinal physiology and intestinal microbiocenosis recovery [102].

Clinical work was preceded by a trial period during which the high rate of enzymatic proteolysis of wheat gluten with proteases tested in vitro strains was proved [103].

Undoubtedly important is the question of the ability of probiotic bacteria to multiply in specific locations. One should take into account the functional place of probiotics when selecting "candidates", because intestinal commensals maximally display their metabolic activity, i.e. have a beneficial effect on human health, only in their particular ecological niches. The joint data shows that members of the genus Lactobacillus providing an environmental protecting barrier of the human body are widespread in the biotope of the gastrointestinal tract, but dominate in the proximal part of the small intestine, whereas bifidus bacteria are prevalent in the colon [104-106]. It is natural that priority should be given to multi-species strains or drugs.

Given the shortage of data on exact mechanisms of probiotic products' effectiveness, data on the functional activity of strains is constantly being refined; functional activity can be stimulated by possible symbiotic relationship.

It is known that L. acidophilus and representatives of the genus Bifidobacterium grow slowly in milk, because they do not decompose proteins due to the almost complete absence of bacterial proteases. Addition of typical yoghurt strains, particularly L. delbrueckii subspecies bulgaricus, is the most physiological way of increasing the number of source types of bacterial cells. This is partly due to the potential impact of cooperative interaction with the exchange of the products of bacterial metabolism: amino acids, peptides, free, formate and CO2 [107].

Experimental data published showed the marked increase in the level of B. animalis in the presence of $L$. acidophilus, which hydrolyzes milk casein using extracellular proteases, thus forming amino acids and peptides able to stimulate breeding population of B. animalis [108].

According to another study, analogous situation was proved in respect to the same species of bacteria, only from the other side: the growth of L. acidophilus strain was amplified by B. animalis, probably, due to a metabolite such as acetate [109].

These arguments suggest that symbiotic relationship in most cases occurs not on the level of species, but rather on the strain level. It is well known today that strains belonging to the genera of Lactobacillus, Lactococcus, Streptococcus, Bifidobacterium и Propionibacterium, demonstrate symbiotic relationship with each other, which, of course, is essential in determining the structure of communities in the microflora and metabolic activity of gut bacteria, which, if possible, should be benign. 
It is advisable to emphasize that the use of combined drugs with combined additive or synergistic strain-specific effects should refer to the current tendencies in the probiotic therapy.

There is an obvious need in further research related to the creation of individual probiotics based on autostrains and autoassociations of symbiotic microorganisms [110]. Today we have documentally proved value of microbial exometabolites that are actively involved in the restoration of human intestinal microflora. These data provide a strong impetus to the development of biotechnology of new generation standardized probiotics [111].

As a practical illustration, one can cite a number of innovative probiotic RioFlora complexes with full scientific dossier justifying the differential control of microbial indigenous microflora cells. Until now, there have been 2 probiotics of the type: both multi-species and multi-strain probiotic drugs that are able to fulfill a specific function of the intestinal microflora in different clinical situations. One of the most important characteristics of these probiotics is their purposeful selection of strains and the presence of a special matrix, which simulates intestinal biofilm, thus ensuring conservation of the number of viable microorganisms when passing through the gastrointestinal tract, thus ensuring probiotic potential as well. 2 probiotic complexes are represented in the Russian Federation, designed for adults and children over the age of 3 .

RioFlora Balance Neo is a probiotic that has a fixed combination of 8 viable bacteria from following production strains: B. bifidum W23, B. lactis W51, L. acidophilus W37, L. acidophilus W55, Lactobacillus paracasei W20, L. plantarum W62, L. rhamnosus W71, Lactobacillus salivarius W24.

Each enteric capsule contains at least $5 \times 108 \mathrm{CFU} /$ caps. microorganisms which have a wide range of physiological effects. Currently, the major research centers in Russia have begun clinical trials in order to obtain their own experience on the use of drugs considered to treat patients with a various disease nosologies and course severity of the process. This will allow standardizing approaches to treatment based on current scientific evidence for all doctors.

Table 1. The studied probiotic microorganisms

\begin{tabular}{|c|c|c|c|}
\hline Lactobateria & bifidus bacteria & Other & Fungi \\
\hline$L$. & $B$. & S. thermophilus & Saccharomyces \\
\hline acidophilus & bifidum & Enterococcus & cerevisiae \\
\hline L. casei & $B$. & faecium & Saccharomyces \\
\hline$L$. & infantis & Propionibacterium & boulardii \\
\hline delbrueckii, & B. & freudenreichii & \\
\hline
\end{tabular}




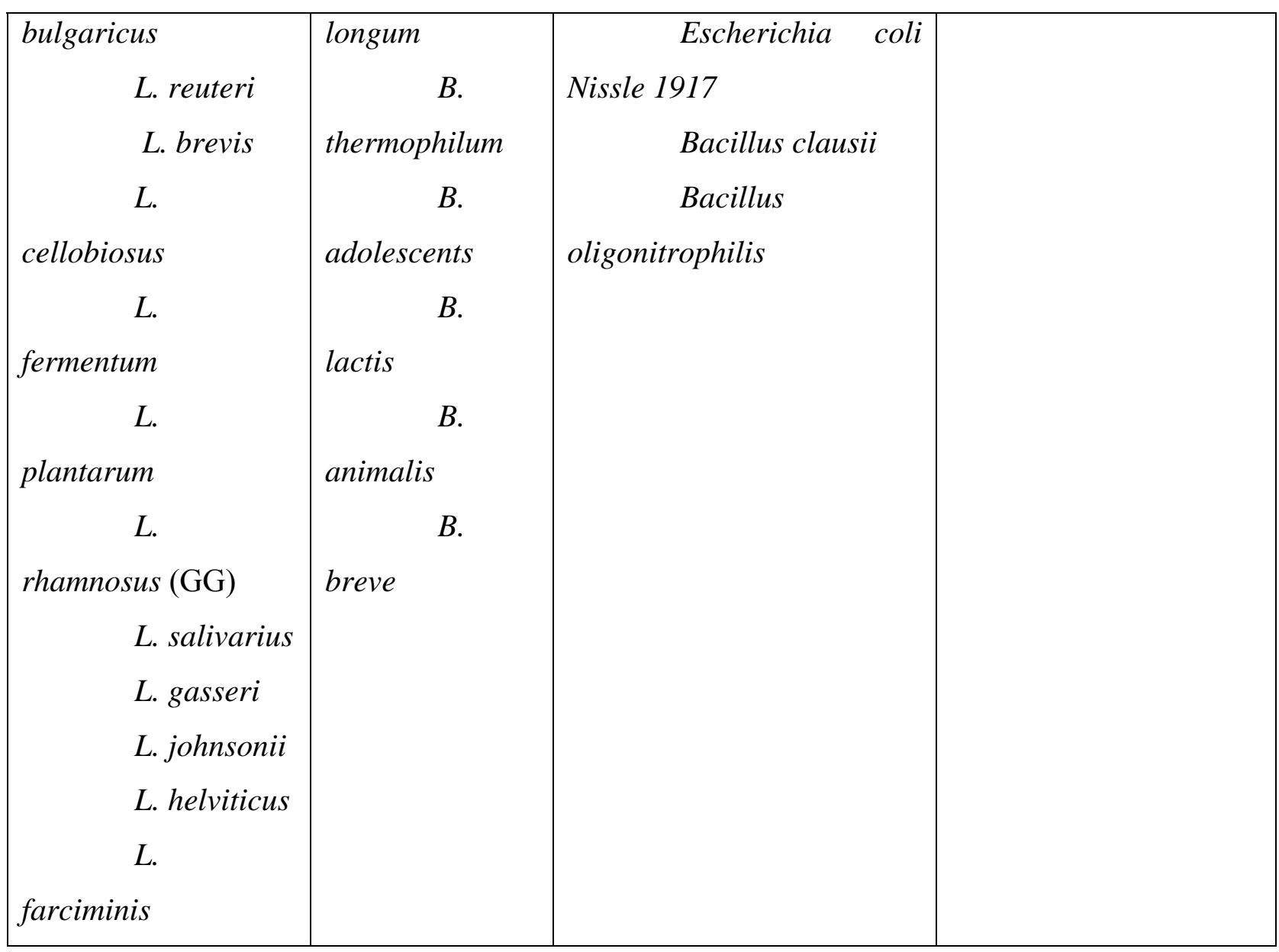

Table 2. The clearest evidence of the biological probiotic microorganisms' effects

\begin{tabular}{|c|c|c|}
\hline Antibacterial effect & $\begin{array}{l}\text { Reinforcement of the } \\
\text { epithelial barrier function }\end{array}$ & $\begin{array}{l}\text { Modulation of immune } \\
\text { response of the host }\end{array}$ \\
\hline $\begin{array}{l}<\mathrm{pH} \text { of the intestinal lumen } \\
\text { Stimulation of the secretion of } \\
\text { defensins } \\
\text { The secretion of antimicrobial } \\
\text { peptides } \\
\text { Inhibition of pathogenic } \\
\text { invasion } \\
\text { Blockade of bacterial adhesion } \\
\text { to epithelial cells } \\
\text { Formation of nitric oxide }\end{array}$ & $\begin{array}{l}\text { Protein phosphorylation of } \\
\text { dense cell contacts } \\
\text { Increase in mucus production } \\
\text { Increased glycosylation of } \\
\text { membranes' components of } \\
\text { epithelial cells } \\
\text { The increase in sIgA } \\
\text { production }\end{array}$ & $\begin{array}{l}\text { Stimulation of antibody } \\
\text { production } \\
\text { Stimulation of NK-cells } \\
\text { Modulation of functional } \\
\text { activity of dendritic cells } \\
\text { Modulation of gene } \\
\text { expression regulators: NF-kB } \\
\text { and AP-1 } \\
\text { Change in cytokine production } \\
\text { The induction of regulatory T } \\
\text { cells } \\
\text { PPAR } \gamma \text { Induction } \\
\text { Modulation of apoptosis } \\
\text { Inhibition of proteasome }\end{array}$ \\
\hline
\end{tabular}


Table 3. Indications based on the evidence for the use of probiotics in gastroenterology

\begin{tabular}{|c|c|c|}
\hline Indications & Probiotic strain & $\begin{array}{r}\text { Dose } \\
\text { prescribed }\end{array}$ \\
\hline $\begin{array}{l}\text { Treatment of } \\
\text { acute intestinal infections } \\
\text { (AII) in children }\end{array}$ & $\begin{array}{l}\text { L. rhamnosus GG } \\
\text { L. reuteri ATTTC } 55730 \\
\text { L. acidophilus + B. infantis } \\
\text { S. cerevisiae (boulardii) }\end{array}$ & $\begin{array}{l}10^{10}-10^{11} \mathrm{BID} \\
10^{1 \mathrm{o}}-10^{11} \mathrm{BID} \\
10^{9} \mathrm{TID} \\
200 \mathrm{mg} \text { TID }\end{array}$ \\
\hline $\begin{array}{l}\text { Treatment of AII } \\
\text { in adults }\end{array}$ & Enterococcus faecium LAB SF & $10^{8} \mathrm{TID}$ \\
\hline $\begin{array}{l}\text { Complete } \\
\text { prevention of (AAD) in } \\
\text { children }\end{array}$ & $\begin{array}{l}\text { S. cerevisiae (boulardii) } \\
\text { L. rhamnosus GG } \\
\text { B. lactis } \mathrm{BB} 12+S \text {. } \\
\text { thermophilus }\end{array}$ & $\begin{array}{l}250 \mathrm{mg} \text { TID } \\
10^{10} \mathrm{OD} / \mathrm{BID} \\
10^{7}+10^{6}\end{array}$ \\
\hline $\begin{array}{l}\text { Prevention of AAD in } \\
\text { adults }\end{array}$ & $\begin{array}{l}\text { Enterococcus faecium LAB SF } \\
68 \\
\text { S. cerevisiae (boulardii) } \\
\text { L. rhamnosus GG } \\
\text { L. casei DN-114001 in } \\
\text { fermented milk with L. bulgaricus }+ \text { S. } \\
\text { thermophilus } \\
\text { L. acidophilus CL1285 }+ \text { L. } \\
\text { casei Lbc80r } \\
\text { Bacillus clausii }\end{array}$ & $\begin{array}{l}10^{8} \text { BID } \\
1 \text { g per day } \\
10^{10}-10^{11} \text { BID } \\
10^{10} \text { BID } \\
5 \times 10^{10} \text { BID } \\
2 \times 10^{9} \text { TID }\end{array}$ \\
\hline $\begin{array}{l}\text { Prevention of nosocomial } \\
\text { diarrhea in children }\end{array}$ & $\begin{array}{l}\text { L. rhamnosus GG } \\
\text { B. lactis } \mathrm{BB} 12+\mathrm{S} . \\
\text { thermophilus }\end{array}$ & $\begin{array}{l}10^{10}-10^{11} \mathrm{BID} \\
10^{8}+10^{7}\end{array}$ \\
\hline
\end{tabular}




\begin{tabular}{|c|c|c|}
\hline & $\begin{array}{l}\text { B. lactis BB } 12 \\
\text { L. reuteri ATTTC } 55730\end{array}$ & $\begin{array}{l}10^{9} \mathrm{BID} \\
10^{9} \mathrm{BID}\end{array}$ \\
\hline $\begin{array}{l}\text { Prevention of diarrhea } \\
\text { caused by C. difficile in } \\
\text { adults }\end{array}$ & $\begin{array}{l}\text { L. casei DN-114001 in } \\
\text { fermented milk with L. bulgaricus }+ \text { S. } \\
\text { thermophilus } \\
\text { L. acidophilus }+ \text { B. bifidum } \\
\text { S. cerevisiae (boulardii) }\end{array}$ & $\begin{array}{l}10^{10} \mathrm{BID} \\
2 \times 10^{10} \mathrm{OD} \\
2 \times 10^{10} \mathrm{OD}\end{array}$ \\
\hline $\begin{array}{l}\text { Adjuvant therapy at } \\
\text { eradication of } H \text {. pylori }\end{array}$ & $\begin{array}{l}\text { L. rhamnosus GG } \\
\text { L. casei DN-114001 in } \\
\text { fermented milk with L. bulgaricus }+S \text {. } \\
\text { thermophilus } \\
\text { S. cerevisiae (boulardii) } \\
\text { Bacillus clausii }\end{array}$ & $\begin{array}{l}6 \times 10^{9} \mathrm{BID} \\
10^{10} \mathrm{BID} \\
1 \mathrm{~g} \text { per day } \\
2 \times 10^{9} \mathrm{TID}\end{array}$ \\
\hline $\begin{array}{l}\text { The decrease of some } \\
\text { symptoms at irritable } \\
\text { bowel syndrome }\end{array}$ & $\begin{array}{l}\text { L. rhamnosus GG } \\
\text { B. infantis } 35624 \\
\text { VSL\#3 mixture } \\
\text { L. rhamnosus GG, L. } \\
\text { rhamnosus LC705, B. breve BB99, } \\
\text { Propionibacterium freudenreichii ssp. } \\
\text { shermanii } \\
\text { B. animalis DN-173 } 010 \text { in } \\
\text { fermented milk with L. bulgaricus }+ \text { S. } \\
\text { thermophilus }\end{array}$ & $\begin{array}{l}6 \times 10^{9} \text { BID } \\
10^{8} \text { per day } \\
4,5 \times 10^{11} \text { BID } \\
10^{10} \text { per day }\end{array}$ \\
\hline
\end{tabular}




\begin{tabular}{|c|c|c|}
\hline & & $10^{10} \mathrm{BID}$ \\
\hline $\begin{array}{l}\text { Remission maintenance at } \\
\text { ulcerative colitis }\end{array}$ & E. coli Nissle 1917 & $5 \times 10^{10} \mathrm{BID}$ \\
\hline $\begin{array}{l}\text { Prevention and remission } \\
\text { maintenance at puoschitis }\end{array}$ & $\begin{array}{l}\text { VSL\#3 mixture of } 8 \text { strains (1 } \\
\text { S. thermophilus, } 4 \text { Lactobacillus, } 3 \\
\text { Bifidobacterium) }\end{array}$ & $4,5 \times 10^{11} \mathrm{BID}$ \\
\hline $\begin{array}{l}\text { Prevention of necrotizing } \\
\text { enterocolitis in preterm } \\
\text { infants }\end{array}$ & $\begin{array}{l}\text { B. infantis, S. thermophilus, B. } \\
\text { bifidum } \\
\text { L. acidophillus + B. infantis }\end{array}$ & $\begin{array}{l}0,35 \times 10^{9} \text { of each strain } \\
\text { BID } \\
10^{9} \text { of each strain BID }\end{array}$ \\
\hline
\end{tabular}

Table 4. Differences between monostrain and multi-species probiotics.

\begin{tabular}{|c|c|}
\hline Monostrain probiotic & Multi-species probiotic \\
\hline \multicolumn{2}{|c|}{ Successful colonization } \\
\hline $\begin{array}{l}\text { Survival depends on the specific } \\
\text { properties of the strain: } \\
\text { The strain should independently } \\
\text { overcome all stress barriers of gastrointestinal } \\
\text { tract }\end{array}$ & $\begin{array}{l}\text { Different strains with specific traits } \\
\text { are more likely to colonize: } \\
\text { of reduction in antagonistic activity } \\
\text { strains } \\
\text { - creation of optimal pH } \\
\text { - creation of an anaerobic niche }\end{array}$ \\
\hline
\end{tabular}




\begin{tabular}{|c|c|}
\hline & $\begin{array}{l}\bullet \text { improvement of bacteria } \\
\text { adhesion }\end{array}$ \\
\hline \multicolumn{2}{|c|}{ Probiotic effect on the body } \\
\hline $\begin{array}{l}\text { The probiotic effect is limited to the } \\
\text { properties of the strain }\end{array}$ & $\begin{array}{l}\text { The probiotic effect is reinforced } \\
\text { through a combination of the properties of the } \\
\text { strain: } \\
\text { - additive effect of the specific } \\
\text { properties of the strain (colonization of } \\
\text { different niches) } \\
\text { - synergistic effects of different } \\
\text { strains (common probiotic effect may be more } \\
\text { pronounced than the sum of the individual } \\
\text { stimulant effects) } \\
\text { Positive relationship between the } \\
\text { strains increasing their biological activity: } \\
\text { - symbiosis between different } \\
\text { strains, for example, through the metabolites } \\
\text { exchange }\end{array}$ \\
\hline
\end{tabular}

\section{REFERENCES}

1. Shenderov B.A. Meditsinskaya mikrobnaya ekologiya i funktsional'noe pitanie. Probiotiki i funktsional'noe pitanie [Medical Microbial Ecology and Functional Food. Probiotics and Functional Foods]. Moscow, Grant", 2001. 286 p.

2. Szajewska H., Mrukowicz J. Probiotics in the treatment and prevention of acute infectious diarrhea in infants and children: a systematic review of published randomized, double-blind, placebo controlled trials. J Pediatr Gastroenterol Nutr. 2001; 33: 17-25.

3. Bezkorovainy A. Probiotics: determinants of survival and growth in the gut. Am J Clin Nutr. 2001; 73: 399-405.

4. Bondarenko V.M. Farmateka - Pharmateca. 2012; 13: 89-99.

5. Gorbach S. L. Probiotics and gastrointestinal health. Am G Gastroenterol. 2000; 95 (Suppl. 1): $2-4$.

6. Hunter J. O., Madden J. A. A review of the role of the gut microflora in irritable bowel syndrome and the effect of probiotics. Br J Nutr. 2002; 88 (Suppl. 1): 67-72.

7. Marteau P. R., de Vrese M., Cellier C. J., Schrezenmeir J. Protection from gastrointestinal diseases with use of probiotics. Am J Clin Nutr. 2001; 73 (Suppl. 2): 430-36.

8 . Rolfe R. D. The role of probiotic cultures in the control of gastrointestinal health. J Nutr. 2000; 130 (Suppl. 2S): 396-402.

9. Mercenier A., Pavan S., Pot B. Probiotics as biotherapeutic agent: present khuwledge and future prospects. Curr Pharm Des. 2003; 9: 175-91. 
10. Guidelines for the evaluation of probiotics in food: Joint FAO/WHO Working Group meeting. London, Ontario, Canada, 30 April - 1 May. 2002.

11. Shida K., Nanno M. Probiotics and immunology: separating the wheat from the chaff. Trends Immynol. 2008; 29: 565-73.

12. Chapman T. M., Plosker G. L., Figgitt D. P. VSL\#3 probiotic mixture: a review of its use in chronic inflammatory bowel diseases. Drugs. 2006; 66 (10): 1371-87.

13. Rachmilevitz D., Katakura K., Karmeli F. et al. Toll-like receptor 9 signaling mediates the anti-inflammatory effect of Probiotics murine experimental colitis. Gastroenterol. 2004; 126 (2): $520-28$.

14. Bergonzelli G. E., Blum S., Brussow H. et al. Probiotics as a treatment strategy for gastrountestinal diseases? Digestion. 2005; 72: 57-68.

15. Penner R., Fedorak R. N., Madsen K. L. Probiotics and nutraceuticals: non-medicinal treatments of gastrointestinal diseases. Curr Opin Pharmacol. 2005; 5: 596-603.

16. Ghadimi D., Folster-Holst R. Effects of probiotic bacteria and their genomic DNA on TH1/TH2-cytokine production by peripheral blood mononuclear cells (PBMCs) of healthy and allergic subjects. Immunobiology. 2008; 213: 677-92.

17. Metchnikoff E. The prolongation of life. Optimistic studies. London, United Kingdom: William Heinemann. 1907.

18. Reid G. Regulatory and clinical aspects of dairy probiotics. FAO/WHO Expert consultation on evalution of health and nutritional properties of powder milk with live lactic acid bacteria. Cordoba, Argentina, 2001. pp. 1-34.

19. FAO/WHO. The food and agriculture organization of the United Nations and the World Health Organization Joint FAO/WHO expert consultation on evalution of health and nutritional propecties of probiotics in food including powder milk with live lactic acid bacteria. 2001 (10$1)$.

20. Timmerman H. M., Koning C. J. M., Mulder L., Rombouts F. M., Beynen A. C. Monostrain, multistrain and multispecies probiotics. A comparison of functionality and efficacy. Int $J$ Food Microbiol. 2004; 96: 219-33.

21. Salminen S., Isolauri E., Onela T. Gut flora in normal and disordered states. Chemotherapy. 1995; 41 (Suppl. 1): 5-15.

22. Van der Waaij D. Colonization resistance of the Digestive Tract. Japan. 1999. P. 76-81.

23. Postnikova E.A., Pikina A.P., Kafarskaya L.I., Efimov B.A. Zhurn. mikrobiol - Journal of microbiology. 2004; 1: 67-69.

24. Fons M., Gomez A., Karjalainen T. Mechanisms of colonization and colonization resistance of the digestive tract. Microbial Ecol Health Dis Sup. 2000; 2: 240-6.

25. Bry L., Falk P. G., Midtvedt T., Gordon J. I. A model of hostmicrobial interactions in an open mammalian ecosystem. Science. 1996; 273 (5280): 1380-3.

26. Hooper L. V., Xu J., Falk P. G., Midtvedt T., Gordon J. I. A molecular sensor that allows a gut commensal to control its nutrient foundation in a competitive ecosystem. Proc Natl Acad Sci. USA. 1999; 96 (17): 9833-8.

27. Mowat A. M. Anatomical basis of tolerance and immunity to intestinal antigens. Nat Rev Immunol. 2003; 3 (4): 331-41.

28. Kelly D., Conway S., Aminov R. Commensal gut bacteria: mechanisms of immune modulation. Trends Immunol. 2005; 26 (6): 326-33.

29. Mayer L., Shao L. Therapeutic potential of oral tolerance. Nat Rev Immunol. 2004; 4 (6): 407-19.

30. Hawrylowicz C. M., O'Garra A. Potential role of interleukin- 10-secreting regulatory T cells in allergy and asthma. Nat Rev Immunol. 2005; 5 (4): 271-83.

31. Kapsenberg M. L. Dendritic-cell control of pathogen-driven T-cell polarization. Nat Rev Immunol. 2003; 3 (12): 984-93.

32. Holzapfel W. H., Haberer P., Geisen R. et al. Taxonomy and important features of probiotic microorganisms in food and nutrition. Am J Clin Nutr. 2001; 73: 365-73. 
33. Lee Y. K., Lim C. Y., Teng W. L. et al. Quantitative approach in the study of adhesion of lactic acid bacteria to intestinal cells ant their competition with enterobacteria. Appl Envir Microbiol. 2000; 66 (9): 3692-97.

34. O'Sullivan D. J. Screening of intestinal microflora for effective probiotic bacteria. J Ag Food Chem. 2001; 49: 1751-60.

35. Schell M. A., Karmirantzou M., Snel B. et al. The genome sequence of Bifidobacterium longum reflect its adaptation to the human gastrointestinal tract. Proc Natl Sci. USA. 2002; 99 (22): $14422-27$.

36. Tannock G. W. Molecular assessment of intestinal microflora. Am J Clin Nutr. 2001; 73: 410-14.

37. Resta-Lenert S., Barrett K. Live probiotics protect intestinal epithelial cells from the effects of infection with enteroinvasive Escherichia coli. Gut. 2003; 52: 988-997.

38. Putaala H., Salusjarvi T. Effect of four probiotic strains and Echerichia coli O157: H7 on tight junction integrity and cyclooxygenase expression. Res Microbiol. 2008. Doi:10.1016/ j.resmic.2008.08.002.

39. Gill H. S. Probiotic to enhance anti-infective defenses in the gastrointestinal tract. Best Pract Res Clin Gastroenterol. 2003; 17: 755-73.

40. Oksaharju A., Kankainen M., Kekkonen R. A. et al. Probiotic Lactobacillus rhamnosus downregulates FCER1 and HRH4 expression in human mast cell. World J Gastroenterol. 2011; 17: 750-9.

41. Alakomi H. L., Skytta E., Saarela M. et al. Lactic acid permebilizes gram-negative bacteria by disrupting the outer membrane. Applied Environ Microbiol. 2000; 66: 2001-5.

42. Pan X., Chen F., Wu T. et al. The acid, bile tolerance and antimicrobial property of Lactobacillus acidophilus NIT. Food Control. 2008. Doi:10.1016/j.foodcont.2008.08.019. 43. Salminen S., Salminen E. Lactulose lactic acid bacteria intestinal microecology and mucosal protection. Scand J Gastroenterol. 1997; 222: 45-8.

44. Lanning D. K., Rhee K. J., Knight K. L. Intestinal bacteria and development of the Blymphocyte repertoire. Trends Immunol. 2005; 26 (8): 419-25.

45. Cotter P. D., Hill C., Ross R. P. Developing innate immunity for food. Nat Rev Microbiol. 2005; 3: 777-88.

46. Strompfova V., Laukova A. In vitro study on bacteriocin production of Enterococci associated with chickens. Anaerobe. 2007; 13: 228-37.

47. Chavez A. M., Menconi M. J., Hodin R. A. et al. Cytokineinduced intestinal epithelial hyperpermeability: role of nitric oxide. Crit Care Med. 1999; 27: 2246-51.

48. Sobko T., Reinders C. L., Jansson E. A. et al. Gastrointestinal bacteria generate nitric oxide from nitrate and nitrite. Nitric Oxide. 2005; 13: 163-69.

49. Lundberg J. O., Weitzberg E., Cole J. A. et al. Nitrate, bacteria and human health. Nat Rev Microbiol. 2004; 2: 593-602.

50. Lu L., Walker A. Pathologic and physiologic interactions of bacteria with the gastrointestinal epithelium. Am J Clin Nutr. 2001; 73: 1124-30.

51. Lebeer S., Vanderleydes G., De Keersmaecker S. C. Genes and molecules of lactobacillus supporting probiotic action. Microbiol Mol Biol Rev. 2008; 72: 728-64.

52. Perdigon G., Fuller R., Raya R. Lactis acid bacteria and their effect on the immune system. Curr Issues Intest Microbiol. 2001; 2 (1): 27-42.

53. Likhoded V.G., Bondarenko V.M. Antiendotoksinovyi immunitet v regulyatsii chislennosti mikroflory kishechnika [Endotoxin Immunity in the Regulation of the Microflora Size of the Intestinal]. Moscow, Meditsina, 2007. 216 p.

54. Vinderola G., Matar C., Perdigon G. Role of intestinal epithelial cells in immune effects mediated by gram-positive probiotic bacteria: involvement of toll-like receptors. Clin Diagn Lab Immunol. 2005; 12 (9): 1075-84. 
55. Isolauri E., Juntunen M., Rautanen T. et al. A human Lactobacillus strain (Lactobacillus casei sp strain GG) promotes recovery from acute diarrhea in children. Pediatrics. 1991; 88: 9097.

56. Isolauri E., Salminen S., Ouwehand A. C. Microbial-gut interactions in health and disease. Probiotics. Best Pract Res Clin Gastroenterol. 2004; 18: 299-313.

57. Isolauri E., Kirjavainen P. V., Salminen S. Probiotics: role in the treatment of intestinal infection and inflammation. Gut. 2002; 50 (3): 154-59.

58. Walker W. A., Goulet O., Morelli L. et al. Progress in the science of probiotics: from cellular microbiology and applied immunology to clinical nutrition. Eur J Nutr. 2006; 45: 1-18.

59. Bondarenko V.M. Farmateka - Pharmateca. 2010; 2: 26-32.

60. Allen S. J., Okoko B., Martinez E., Gregorio G., Dans L. F. Probiotics for treating infectious diarrhea. Cochrane Database Syst Rev. 2004; 2: CD003048.

61. Lee M. C., Lin L. H., Hung K. L., Wu H. Y. Oral bacterial therapy promotes recovery from acute diarrhea in children. Acta Paediatr. Taiwan. 2001; 42: 301-5.

62. Sazawal S., Hiremath G., Dhingra U. et al. Efficacy of probiotics in prevention of acute diarrhoea: a meta-analysis of masked, randomised, placebo-controlled trials. Lancet Infect Dis. 2006; 6: 474-82.

63. Hickson M., D'Souza A. L., Muthu N. et al. Use of probiotic Lactobacillus preparation to prevent diarrhoea associated with antibiotics: randomised double blind placebo controlled trial. BMJ. 2007; 335 (7610): 80.

64. Nista E. C., Candelli M., Cremonini F. et al. Bacillus clausii therapy to reduce side-effects of anti-Helicobacter pylori treatment: randomized, double-blind, placebo controlled trial. Aliment Pharmacol Ther. 2004; 20: 1181-8.

65. Beausoleil M., Fortier N., Guenette S. et al. Effect of a fermented milk combining Lactobacillus acidophilus C11285 and Lactobacillus casei in the prevention of antibioticassociated diarrhea: a randomized, double-blind, placebo-controlled trial. Can J Gastroenterol. 2007; 21: 732-6.

66. Plummer S., Weaver M. A., Harris J. C. et al. Clostridium difficile pilot study: effects of probiotic supplementation on the incidence of Clostridium difficile diarrhea. Int Microbiol. 2004; 7: 59-62.

67. Tong J. L., Ran Z. H., Shen J. et al. Meta-analysis: the effect of supplementation with probiotics on eradication rates and adverse events during Helicobacter pylori eradication therapy. Aliment Pharmacol Ther. 2007; 25: 155-68.

68. Sykora J., Valeckova K., Amlerova J. et al. Effects of a specially designed fermented milk product containing probiotic Lactobacillus casei DN-114 001 and the eradication Helicobacter pylori in children: prospective randomized double-blind study. J Clin Gastroenterol. 2005; 39: 692-8.

69. O'Mahony L., McCarthy J., Kelly P. et al. Lactobacillus and Bifidobacterium in irritable bowel syndrome: symptom responses and relationship to cytokine profiles. Gastroenterology. 2005; 128: 541-51.

70. Gawronska A., Dziechciarz P., Horvath A., Szajewska H. A randomized double-blind placebo-controlled trial of Lactobacillus GG for abdominal pain disorders in children. Aliment Pharmacol Ther. 2007; 25: 177-84.

71. Kim H. J., Vazquez Roque M. I., Camilleri M. et al. A randomized controlled trial of a probiotic combination VSL\#3 and placebo in irritable bowel syndrome with bloating.

Neurogastroenterol Motil. 2005; 17: 687-96.

72. Kajander K., Hatakka K., Poussa T., Farkkila M., Korpela R. A probiotic mixture alleviates symptoms in irritable bowel syndrome patients: a controlled 6-month intervention. Aliment Pharmacol Ther. 2005; 22: 387-94.

73. Guyonnet D., Chassany O., Ducrotte P. et al. Effect of a fermented milk containing Bifidobacterium animalis DN-173 010 on the health related quality of life and symptoms in irritable bowel syndrome in adults in primary care: a multicentre, randomized, 
double-blind, controlled trial. Aliment Pharmacol Ther. 2007; 26: 475-86.

74. Kruis W., Fric P., Pokrotnieks J. et al. Maintaining remission of ulcerative colitis with the probiotic Escherichia coli Nissle 1917 is as effective as with standard mesalazine. Gut. 2004; 53: 1617-23.

75. Rayes N., Seehofer D., Theruvath T. et al. Supply of preand probiotics reduces bacterial infection rates after liver transplantation - a randomized, double-blind trial. Am J Transplant. 2005; $5: 125-30$.

76. Darmov I.V., Chicherin I.Yu., Pogorel'skii I.P., Lundovskikh I.A. Eksperiment. i klin. gastroenterologiya - Experimental and clinical gastroenterology. 2011; 3: 6-11.

77. Darmov I.V., Chicherin I.Yu., Erdyakova A.S., Pogorel'skii I.P., Lundovskikh I.A. Kishechnaya mikroflora - Intestinal microflora. 2012; 1: 11-15.

78. Deshpande G., Rao S., Patole S. Probiotics for prevention of necrotising enterocolitis in preterm neonates with very low birthweight: a systematic review of randomised controlled trials. Lancet. 2007; 369: 1614-20.

79. Botina S.G., Ivashkina N.Yu., Maev I.V. Molekulyarnaya meditsina - Molecular medicine. $2011 ; 2: 53-57$.

80. Kankainen M., Paulin L., Tynkkynen S. et al. Comparative genomic analysis of Lactobacillus rhamnosus GG reveals pill containing a human mucus binding protein. Proc Natl Acad Sci. USA. 2009; 106 (40): 17193-98.

81. Darmov I.V., Chicherin I.Yu., Pogorel'skii I.P., Lundovskikh I.A., Durnev E.A. Zhurn. infektol. - Journal of infectology. 2012; 4 (1): 68-74.

82. World Gastroenterology Organization practice guideline: Probiotics and prebiotics. Arab J Gastroenterology. 2009; 10 (1): 33-42.

83. Chicherin I.Yu., Darmov I.V., Bogacheva N.V. et al. Kishechnaya mikroflora. Sbornik nauchnykh statei - Intestinal microflora. Collection of papers. 2012; 1: 24-29.

84. Erdyakova A.S., Chicherin I.Yu., Lundovskikh I.A., Pogorel'skii I.P. Kishechnaya mikroflora. Sbornik nauchnykh statei - Intestinal microflora. Collection of papers. 2012; 1: 2123.

85. Marteau P., Shanahan F. Basic aspects and pharmacology of probiotics - an overview on pharmacokinetics, mechanisms of action and side effects. Best Pract Res Clin Gastroenterol. 2003; 17 (5): 725-40.

86. Doronin A.F., Shenderov B.A. Funktsional'noe pitanie [Functional Nutrition]. M.osocw, Grant", 2002. 296 p.

87. Chicherin I.Yu., Darmov I.V., Pogorel'skii I.P. et al. Kishechnaya mikroflora - Intestinal microflora. 2012; 1: 35-40.

88. Famularo G., Di Simone C., Matteuzzi D., Pirovano F. Traditional and high potency probiotic preparations for oral bacteriotherapy. Biodrigs. 1999; 12: 544-70.

89. Sanders M. E., Huis in't Veld J. Bringing a probiotic-containing functional food to the market: microbiological, product, regulatory and labeling issues. Antonie Van Leeuwenhoek. 1999; 76: 293-315.

90. Dunne C., Murphy L., Flynn S., O'Mahony L., O'Halloran. et al. Probiotics: from myth to reality. Demonstration of functionality in animal models of disease and in human clinical trials. Antonie Van Leeuwenhoek. 1999; 76: 279-92.

91. Zoppi G., Cinquetti M., Benini A., Bonamini E., Minelli E. Modulation of the intestinal ecosystem by probiotics and lactulose in children during treatment with ceftriaxone. Curr Therap Res. 2001; 62: 418-35.

92. Shibolet O., Karmeli F., Eliakim R. et al. Variable response to probiotics in two models of experimental colitis in rats. Inflamm Bowel Dis. 2002; 8: 399-406.

93. Ullisse S., Gionchetti P., D'Alo S. et al. Expression of cytokines, inducible nitric oxide synthase, and matrix metalloproteinases in pouchitis; effects of probiotic treatment. Am J Gastroenterol. 2001; 96: 2691-9. 
94. Perdigon G., Nader de Macias Ms E., Alvarez S. et al. Prevention of gastrointestinal infection usingimmunobiological methods with milk fermented with Lactobacillus casei and Lactobacillus acidophilus. J Dairy Res. 1990; 57: 255-64.

95. Lema M., William L., Rao D. R. Reduction of faecal shedding of enterohemorragic Escherichia coli O157: H7 in lambs by feeding microbial feed supplement. Small Rumin Res. 2001; 39: 31-9.

96. van Es M., Timmerman H. M. Onderzoek naar multispecies probiotica voor niet-humane toepassingen. BTS-project 98186. 2002.

97. Gill H. S., Shu Q., Lin H., Rutherfurd K. J., Cross M. L. Protection against translocating Salmonella typhimurium infection in mice by feeding the immuno-enhancing probiotic Lactobacillus rhamnosus strain HNOO1. Med Microbiol Immunol. 2001; 190: 97-104. 98. Frolich-Wyder M. T., Bachmann H. P., Casey M. G. Interactions between propionibacteria and starter/nonstarter lactic acid bacteria in Swiss-type cheese. Lait. 2002; 82: 1-15.

99. Shankar P., Davies F. Associated bacterial growth in yogurt starters, initial abservation on stimulatory factors. J Soc Dairy Technol. 1976; 30: 31-2.

100. Ouwehand A. C., Isolauri E., Kirjavainen P. V. et al. The mucus binding of B. lactis Bb12 is enhanced in the presence of LGG and L. delbrueckii subsp. Bulgaricus. Lett Appl Microbiol. 2000; 30: 10-3.

101. Ouwehand A. C., Suomalainen T., Tolkko S., Salminen S. In vitro adhesion of propionoc acid bacteria to human intestinal mucus. Lait. 2002; 82: 123-30.

102. Yuldasheva D.Kh., Kamilova A.T. Voprosy detskoi dietologii - Problems of pediatric nutritiology.. 2012; 10 (2): 50-52.

103. Yuldasheva D.Kh., Kamilova A.T. Aktual'nye problemy abdominal'noi patologii u detei [Actual Problems of Abdominal Pathology in Children]. Moscow, 2010. pp. 163-164. 104. Walter J. Ecological role of lactobacilli in the gastrointestinal tract: implication for fundamental and biomedical research. Appl Envir Microbiol. 2008; 74 (16): 4985-96. 105. Broad A., Jones D. E., Kirby J. A. Toll-like receptor (TLR) response tolerance: a key physiological «damage limitation» effect and an important potential opportunity for therapy. Curr Med Chem. 2006; 13 (21): 2487-502.

106. Vinderola G., Matar C., Perdigon G. Role of intestinal epithelial cells in immune effects mediated by gram-positive probiotic bacteria: involvement of toll-like receptors. Clin Diagn Lab Immunol. 2005; 12 (9): 1075-84.

107. Driessen F. M., Kingma F., Stadhouder J. Evidence that Lactobacillus bulgaricusin yoghurt is stimulated by carbon dioxide produced by Streptococcus thermophiles. Neth Milk Dairy J. 1982; 36: 135-44.

108. Gomes A. M., Malcata F. X., Klaver F. A. Growth enhance ment of Bifidobacterium lactis and Lactobacillus acidophilus Ki by milk hydrolyzates. J Dairy Sci. 1998; 81: 2817-25.

109. Kailasapathy K., Chin J. Survival and therapeutic potential of probiotic organisms with reference to Lactobacillus acidophilus and Bifidobacterium spp. Immunol Cell Biol. 2000; 78: $80-8$.

110. Tokareva N. Gastroenterologiya - Gastroenterology. 2011; 3: 77-84.

111. Chicherin IYu., Pogorel'skii I.P., Darmov I.V. et al. Prakticheskaya meditsina - Practical medicine. 2012; 3: 47-55. 